\title{
Kondisi Kesehatan Lingkungan Pesantren dan Perilaku Hidup Bersih dan Sehat Siswa dengan Kejadian Hepatitis
}

\author{
Boarding School Environment Health Conditions and Personal Hygiene \\ Students with Hepatitis Incident
}

\author{
Ii Sumarni*, Dewi Susanna**
}

\author{
*Dinas Kesehatan Kabupaten Ciamis, **Departemen Kesehatan Lingkungan Fakultas Kesehatan Masyarakat \\ Universitas Indonesia
}

\begin{abstract}
Abstrak
Kejadian luar biasa hepatitis A di Kabupaten Ciamis telah terjadi beberapa kali, satu di antaranya terjadi di Pondok Pesantren X. Penelitian ini bertujuan untuk menganalisis kondisi kesehatan lingkungan serta perilaku hidup bersih dan sehat dengan kejadian hepatitis A siswa/siswi di Pondok Pesantren X Kabupaten Ciamis. Rancangan penelitian menggunakan desain kasus kontrol dengan jumlah kasus 40 orang dan kontrol 80 orang, total sampel 120 orang. Populasi penelitian adalah siswa/siswi madrasah tsanawiyah dan madrasah aliyah negeri yang tinggal di asrama pondok pesantren. Data kasus merupakan data sekunder yang diperoleh dari Tim Surveilans Kabupaten Ciamis, dengan hasil pemeriksaan serologis positif. Sedangkan kontrol berdasarkan tidak adanya gejala klinis. Data kondisi kesehatan lingkungan serta perilaku hidup bersih dan sehat diperoleh langsung dengan observasi dan wawancara menggunakan kuesioner. Hasil analisis bivariat menunjukan, usia, kebiasaan minum air masak, kebiasaan makan bersama antar teman, tukar menukar alat makan, dan kebiasaan jajan merupakan variabel yang berhubungan dengan kejadian hepatitis $A$. Hasil analisis multivariat dengan uji regresi logistik ganda diperoleh tiga variabel yang berhubungan dengan kejadian hepatitis $A$, yaitu kebiasaan makan bersama dalam satu tempat $(O R=21,48)$, kebiasaan tukar menukar alat makan $(O R=6,15)$, dan status imunisasi sebagai faktor pencegah hepatitis $A(O R=0,056)$. Risiko responden apabila belum diimunisasi hepatitis $A$ serta terbiasa tukar menukar alat dan makan bersama dalam satu tempat adalah 3, 36 kali untuk terjadinya hepatitis $A$.

Kata kunci: Hepatitis A, kebiasaan makan bersama, kondisi kesehatan lingkungan, perilaku hidup bersih dan sehat
\end{abstract}

\section{Abstract}

Hepatitis A outbreaks in Ciamis District has occurred several times, one of them has occurred in X Islamic Boarding School in 2012. This research aimed to analyze environment health condition dan personal hygiene with incident of hepatitis A among students in X Islamic Boarding School Ciamis
District. The research used case control with 40 cases and 80 controls, total 120 subjects. The research population are students of tsanawiah madrassa and aliyah public madrassa who stayed at Islamic boarding school. The case data was secondary data gained from Ciamis District Surveilance Team, with the examination result was serologically positive. Meanwhile, the control was based on no clinical symptoms found. The data of environment health condition and personal hygiene was gained directly from the observation and interview by questionnaire. The Chi-Square test analysis showed that age, drinking habit, food sharing habit, utensil exchanging, and snack habit were the variables which related to hepatitis $A$ incidence. The logistic regression analysis test gained of three variables which related to hepatitis $A$ incidents, they are food sharing habit $(O R=$ 21.48), utensil exchanging habit $(O R=6.15)$, and immunization status as prevention factor $(O R=0.056)$. The risk of respondents who did not had hepatitis A immunization and had utensil exchanging habit and food sharing was 3,36 times for hepatitis A infection.

Keywords: Hepatitis A, food sharing, environment condition, personal hygiene

\section{Pendahuluan}

Pemerintah dan masyarakat bertanggung jawab melakukan upaya pencegahan, pengendalian, dan pemberantasan penyakit menular serta akibat yang ditimbulkannya, salah satu penyakit menular tersebut adalah hepatitis A. ${ }^{1}$ Penyakit hepatitis A adalah penyakit peradangan hati yang disebabkan oleh virus hepatitis A (HAV). Penyakit yang dikenal sebagai penyakit kuning (jaundice) ini penularannya berbeda dengan virus

Korespondensi: Ii Sumarni, Dinas Kesehatan Kabupaten Ciamis, Jl. Mr. Iwa Kusumasomantri No.12 Ciamis, No.Telp: 0265-773828, e-mail: sumarni2902@gmail.com 
Hepatitis B ( $H B V)$ dan Virus Hepatitis C $(H C V)$, yakni melalui makanan dan minuman yang tercemar kotoran yang mengandung virus hepatitis A. ${ }^{2}$ Hepatitis A merupakan penyakit menular yang sering sekali menimbulkan wabah di dunia. Sebanyak 1,4 juta pasien mengalami serangan hepatitis A tiap tahunnya. ${ }^{3}$ Hingga saat ini hepatitis $\mathrm{A}, \mathrm{B}$ dan $\mathrm{C}$ masih menjadi masalah kesehatan dunia karena berpotensi menimbulkan dampak morbiditas dan mortalitas. Hepatitis A merupakan self limiting disease tetapi dapat menimbulkan dampak epidemiologis dan klinis. ${ }^{4}$

Tahun 2010 prevalensi penyakit hepatitis A di Indonesia mencapai angka $9.3 \%$ dari total penduduk 237.6 juta jiwa. ${ }^{5}$ Berdasarkan laporan surveilans Kabupaten Ciamis selama tahun 2012 kejadian luar biasa (KLB) hepatitis A di Kabupaten Ciamis sudah mencapai 218 kasus, kasus tersebut terjadi di Kecamatan Panumbangan, Ciamis, dan Lakbok. ${ }^{6}$ Salah satu tempat kejadian luar biasa hepatitis A adalah di Pondok Pesantren X, sebanyak 40 siswa-siswi Madrasah Aliyah dan Tsanawiyah dinyatakan positif terinfeksi Virus Hepatitis A. Jumlah santri Pondok Pesantren X mencapai 425 orang yang seluruhnya tinggal di asrama. Berdasarkan hasil investigasi Tim Surveilans Epidemiologi Kabupaten Ciamis, ada beberapa faktor risiko yang mungkin menyebabkan terjadinya kasus. Diantaranya kualitas air bersih, Perilaku Hidup Bersih dan Sehat, higiene sanitasi dapur umum, kantin sekolah dan warung. Penelitian ini bertujuan untuk menganalisis kondisi kesehatan lingkungan dan Perilaku Hidup Bersih dan sehat (PHBS) dengan kejadian hepatitis A siswa siswi di Pondok Pesantren X Kabupaten Ciamis.

\section{Metode}

Penelitian ini menggunakan desain kasus kontrol, merupakan studi observasional yang menilai hubungan paparan dan penyakit. Studi ini dapat mengetahui hubungan antara kondisi kesehatan lingkungan dan perilaku hidup bersih dan sehat dengan kejadian Hepatitis A di Asrama Pondok Pesantren X Kabupaten Ciamis tahun 2012. Lokasi penelitian adalah di Pondok Pesantren X Kabupaten Ciamis.

Populasi penelitian adalah seluruh siswa/siswi Madrasah Aliyah dan Tsanawiyah yang tinggal di asrama pondok pesantren. Sampel penelitian terbagi dua yaitu sampel kasus, diperoleh dari data siswa/siswi Madrasah Aliyah dan Tsanawiyah Pondok Pesantren X Kecamatan Cijeungjing Kabupaten Ciamis yang menderita Hepatitis A berdasarkan pemeriksaan fisik oleh petugas kesehatan puskesmas, rumah sakit dan praktik swasta, serta didiagnosa mempunyai gejala klinis hepatitis A (lesu, mata kuning, urine seperti air teh) dan setelah pemeriksaan serologis menunjukan hasil $\operatorname{Ig} M$-anti $H A V$ postitif. Penegakan diagnosis untuk kasus dilakukan saat kasus menderita gejala (pada saat kejadian luar biasa). Sedangkan sampel kontrol diperoleh dari data siswa/siswi Madrasah Aliyah dan Tsanawiyah Pondok Pesantren X Kecamatan Cijeungjing Kabupaten Ciamis yang tidak mempunyai gejala klinis Hepatitis A (lesu, mata kuning, urin seperti air teh). Data seluruh siswa tersebut diperoleh dari Kantor Pusat Yayasan Pondok Pesantren X. Hasil pengambilan data tersebut diperoleh 40 orang yang positif Hepatitis A dan 385 negatif Hepatitis A.

Jumlah sampel dalam penelitian ini dihitung berdasarkan rumus uji hipotesis beda dua proporsi menurut Lemeshow, ${ }^{7}$ diperoleh besar sampel minimal yang dibutuhkan sebesar 108 sampel. Dalam penelitian ini sampel kasus dan kontrol akan diambil perbandingan $1: 2$, sehingga sampel kasus 40 dan kontrol adalah 80 orang, dan total sampel keseluruhan adalah 120 orang.

Data sekunder kasus infeksi hepatitis A dan kontrol diperoleh dari hasil pemeriksaan gejala klinis dan serologis HAV-IgM, yang dilakukan oleh tenaga kesehatan baik swasta maupun pemerintah terhadap siswa/siswi Madrasah Aliyah dan Tsanawiyah Pondok Pesantren X Ciamis. Data tersebut diperoleh dari Seksi P4B Bidang P2PL Dinas Kesehatan Kabupaten Ciamis tahun 2012. Data primer didapat dengan melakukan wawancara dengan instrumen kuesioner serta observasi langsung.

Analisis data dilakukan secara univariat, bivariat dan multivariat. Derajat hubungan antara variabel independen dengan variabel dependen didapat dari odds ratio (OR). ${ }^{8}$ Analisis multivariat menggunakan uji regresi logistik ganda dengan model risiko karena baik variabel dependen maupun independen merupakan jenis data kategorik. Uji multivariat dilakukan pada hasil uji bivariat menghasilkan nilai $\mathrm{p}<0,25$ maka variabel tersebut dapat dimasukkan dalam model multivariat. Namun, bila variabel dengan nilai $p>0,25$ secara substansi penting, variabel tetap dimasukan ke dalam model. Pada pembuatan model faktor penentu, dalam pemodelan ini semua variabel kandidat dimasukan secara bersamaan. Model terbaik didapatkan dengan mempertimbangkan dua penilaian yaitu nilai signifikan rasio log-likehood dan nilai signifikan nilai $\mathrm{p}<0,05)$. Variabel-variabel yang nilai $\mathrm{p}<$ 0,05 akan masuk ke dalam model sedangkan variabelvariabel yang nilai $\mathrm{p}>0,05$ akan dikeluarkan dari model. Pengeluaran variabel dilakukan secara bertahap, dimulai dari variabel yang mempunyai nilai $\mathrm{p}$ terbesar sampai tidak ada lagi variabel dengan nilai $p>0,05 .{ }^{9}$

\section{Hasil}

Hasil observasi terhadap kondisi kesehatan lingkungan diperoleh kualitas air bersih, dari empat sumur yang diperiksa hanya dua sumur yang memenuhi syarat. Kualitas sarana air bersih sumur $(50 \%)$ berisiko tinggi dan amat tinggi. Kualitas jamban di asrama putra seba- 
gian besar $(76,9 \%)$ tidak memenuhi syarat. Di asrama putri, 55\% tidak memenuhi syarat. Kondisi higiene sanitasi dapur umum tidak memenuhi syarat karena tata letak ruangan tidak sesuai proses, tidak ada loker untuk pegawai, lantai kotor, tidak kedap air dan tidak rata, begitu juga dengan atap dan langit-langit sangat kotor, pintu dapur tidak rapat serangga. Penjamah makanan yang bertugas di dapur berjumlah 8 orang, 6 orang perempuan dan 2 orang laki-laki. Seluruh penjamah tersebut belum pernah mengikuti kursus higiene sanitasi makanan, tidak mengenakan baju kerja secara khusus, serta tidak memiliki kartu kesehatan karyawan. Kondisi tempat makan tidak memenuhi syarat karena bukan suatu ruangan. Hanya meja yang dijejerkan di depan asrama kualitas tempat cuci tangan memenuhi syarat. Kualitas tempat cuci alat makan kurang memenuhi syarat, karena kotor, retak-retak dan tidak tersedia sabun.

Berdasarkan hasil uji statistik terhadap 4 karakteristik responden, diperoleh hasil yaitu usia tidak berhubungan dengan kejadian hepatitis A $(0,19 ; 1,96 ; 0,82$ 4,68), jenjang pendidikan tidak berhubungan dengan kejadian Hepatitis A $(0,65 ; 1,29 ; 0,60-2,77)$ serta jenis kelamin tidak berhubungan dengan kejadian hepatitis A $(1,0 ; 1,0 ; 0,45-2,22)$, sedangkan status imunisasi merupakan faktor protektif (mengurangi risiko) $(0,00 ; 0,09$; $0,02-0,43)$ (Tabel 1).

Hasil analisis antara kondisi kesehatan lingkungan (kualitas fisik dan bakteriologi air bersih) diperoleh bahwa seluruh responden baik kasus maupun kontrol menggunakan air bersih yang memenuhi syarat sehingga secara statistik tidak dapat dianalisis. Kualitas sarana air bersih, seluruh responden baik kasus maupun kontrol menggunakan sarana air bersih yang tidak memenuhi syarat sehingga secara statistik tidak dapat dianalisis. Kualitas tempat cuci alat makan, seluruh responden baik kasus maupun kontrol menggunakan tempat cuci makan yang tidak memenuhi syarat sehingga secara statistik tidak dapat dianalisis. Kualitas dapur umum, seluruh responden baik kasus maupun kontrol untuk keperluan makan dilayani dari dapur umum yang tidak memenuhi syarat, sehingga secara statistik tidak dapat dianalisis. Begitu juga dengan higiene sanitasi tempat makan dengan kejadian hepatitis A pada responden tidak dapat dianalisis secara statistik karena datanya konstan pada satu kategori variabel. Variabel kualitas jamban dan kualitas tempat cuci tangan tidak ada yang berhubungan karena seluruhnya memperoleh nilai $\mathrm{p}>0,05$ (Tabel 2).

Hasil analisis hubungan perilaku hidup bersih dan sehat dengan kejadian hepatitis A terdapat 4 variabel yang berhubungan yaitu kebiasaan responden meminum air, tukar menukar alat makan, makan bersama dalam satu tempat dan kebiasaan jajan (Tabel 3).

Selanjutnya dilakukan analisis multivariaat dengan pemilihan variabel kandidat dilakukan dengan cara memilih hasil seleksi bivariat terhadap variabel yang

Tabel 1. Hasil Analisis Hubungan Karakteristik Responden dengan Kejadian Hepatitis A

\begin{tabular}{|c|c|c|c|c|c|c|c|c|c|c|}
\hline \multirow{3}{*}{ Karakteristik Responden } & \multirow{3}{*}{ Kategori } & \multicolumn{6}{|c|}{ Status Responden } & \multirow{3}{*}{ Nilai p } & \multirow{3}{*}{ OR } & \multirow{3}{*}{ CI 95\% } \\
\hline & & \multicolumn{2}{|c|}{ Kasus } & \multicolumn{2}{|c|}{ Kontrol } & \multicolumn{2}{|c|}{ Total } & & & \\
\hline & & $\mathbf{n}$ & $\%$ & $\mathbf{n}$ & $\%$ & $\mathbf{n}$ & $\%$ & & & \\
\hline \multirow[t]{2}{*}{ Umur } & $12-16$ & 31 & 77,5 & 51 & 63,8 & 82 & 68,3 & 0,19 & 1,96 & $0,82-4,68$ \\
\hline & $17-25$ & 9 & 22,5 & 29 & 36,3 & 38 & 31,7 & & & \\
\hline \multirow[t]{2}{*}{ Jenjang pendidikan } & MTs & 19 & 47,5 & 33 & 41,2 & 52 & 43,3 & 0,65 & 1,29 & $0,60-2,77$ \\
\hline & MAN & 21 & 52,5 & 47 & 58,8 & 68 & 56,7 & & & \\
\hline \multirow[t]{2}{*}{ Jenis kelamin } & Laki-laki & 14 & 35,0 & 28 & 35,5 & 42 & 35,0 & 1,00 & 1,00 & $0,45-2,22$ \\
\hline & Perempuan & 26 & 65,0 & 52 & 65,0 & 78 & 65,0 & & & \\
\hline \multirow[t]{2}{*}{ Status imunisasi } & Tidak & 31 & 77,5 & 78 & 97,5 & 109 & 90,8 & 0,00 & 0,09 & $0,02-0,43$ \\
\hline & Ya & 9 & 22,5 & 2 & 2,5 & 11 & 9,2 & & & \\
\hline
\end{tabular}

Tabel 2. Hasil Analisis Hubungan Kondisi Kesehatan Lingkungan dengan Kejadian Hepatitis A

\begin{tabular}{|c|c|c|c|c|c|c|c|c|c|c|}
\hline \multirow{3}{*}{ Kondisi Kesehatan Lingkungan } & \multirow{3}{*}{ Kategori } & \multicolumn{6}{|c|}{ Hepatitis A } & \multirow{3}{*}{ Nilai p } & \multirow{3}{*}{ OR } & \multirow{3}{*}{ CI 95\% } \\
\hline & & \multicolumn{2}{|c|}{ Kasus } & \multicolumn{2}{|c|}{ Kontrol } & \multicolumn{2}{|c|}{ Total } & & & \\
\hline & & $\mathbf{n}$ & $\%$ & $\mathbf{n}$ & $\%$ & $\mathbf{n}$ & $\%$ & & & \\
\hline \multirow[t]{2}{*}{ Kualitas jamban } & TMS & 17 & 42,5 & 28 & 35,0 & 45 & 37,5 & 0,55 & 1,37 & $0,63-2,99$ \\
\hline & MS & 23 & 57,5 & 52 & 65,0 & 75 & 62,5 & & & \\
\hline \multirow[t]{2}{*}{ Kualitas tempat cuci tangan } & TMS & 1 & 2,5 & 0 & 0 & 1 & 0,8 & 0,33 & 3,05 & $2,36-3,95$ \\
\hline & MS & 39 & 97,5 & 80 & 100 & 119 & 99,2 & & & \\
\hline
\end{tabular}

*TMS: Tidak memenuhi syarat, MS: Memenuhi syarat 
Tabel 3. Hasil Analisis Hubungan Perilaku Hidup Bersih dan Sehat dengan Kejadian Hepatitis A

\begin{tabular}{|c|c|c|c|c|c|c|c|c|c|c|}
\hline \multirow{3}{*}{ Perilaku Hidup Bersih dan Sehat } & \multirow{3}{*}{ Kategori } & \multicolumn{6}{|c|}{ Hepatitis A } & \multirow{3}{*}{ Nilai p } & \multirow{3}{*}{ OR } & \multirow{3}{*}{ CI 95\% } \\
\hline & & \multicolumn{2}{|c|}{ Kasus } & \multicolumn{2}{|c|}{ Kontrol } & \multicolumn{2}{|c|}{ Total } & & & \\
\hline & & $n=40$ & $\%$ & $\mathrm{n}=\mathbf{8 0}$ & $\%$ & $n=120$ & $\%$ & & & \\
\hline \multirow[t]{2}{*}{ Cuci tangan sebelum makan } & Tidak & 8 & 20,0 & 21 & 26,3 & 29 & 24,2 & 0,60 & 0,70 & $0,28-1,76$ \\
\hline & $\mathrm{Ya}$ & 32 & 80,0 & 59 & 73,8 & 91 & 75,8 & & & \\
\hline \multirow[t]{2}{*}{ Cuci tangan pakai sabun } & Tidak & 16 & 40,0 & 38 & 47,5 & 54 & 45,0 & 0,56 & 0,74 & $0,34-1,60$ \\
\hline & Ya & 24 & 60,0 & 42 & 52,5 & 66 & 55,0 & & & \\
\hline \multirow[t]{2}{*}{ Cuci alat makan/minum pakai sabun } & Tidak & 3 & 7,5 & 12 & 15,0 & 15 & 12,5 & 0,38 & 0,46 & $0,12-0,73$ \\
\hline & Ya & 37 & 92,5 & 68 & 85,0 & 105 & 87,5 & & & \\
\hline \multirow[t]{2}{*}{ Cuci tangan setelah BAB } & Tidak & 5 & 12,5 & 5 & 6,3 & 10 & 8,3 & 0,30 & 2,14 & $0,58-7,89$ \\
\hline & Ya & 35 & 87,5 & 75 & 93,8 & 110 & 91,7 & & & \\
\hline \multirow{2}{*}{ Kebiasaan minum air yang masak } & Tidak & 35 & 87,5 & 52 & 65,0 & 87 & 72,5 & 0,02 & 3,77 & $1,33-10,70$ \\
\hline & $\mathrm{Ya}$ & 5 & 12,5 & 28 & 35,0 & 33 & 27,5 & & & \\
\hline \multirow[t]{2}{*}{ Kebiasaan makan makanan yang masak } & Tidak & 2 & 5,0 & 0 & 0 & 2 & 1,7 & 0,11 & 3,11 & $2,39-4,03$ \\
\hline & $\mathrm{Ya}$ & 38 & 95,0 & 80 & 100 & 118 & 98,3 & & & \\
\hline \multirow[t]{2}{*}{ Kebiasaan BAB di WC dengan septik tank } & Tidak & 2 & 5,0 & 7 & 8,8 & 9 & 7,5 & 0,72 & 0,55 & $0,11-2,77$ \\
\hline & $\mathrm{Ya}$ & 38 & 95,0 & 73 & 91,2 & 111 & 92,5 & & & \\
\hline \multirow[t]{2}{*}{ Kebiasaan tukar menukar alat makan } & $\mathrm{Ya}$ & 30 & 75,0 & 10 & 12,5 & 40 & 33,3 & 0,00 & 21 & $7,92-55,69$ \\
\hline & Tidak & 10 & 25,0 & 70 & 87,5 & 80 & 66,7 & & & \\
\hline \multirow[t]{2}{*}{ Kebiasaan makan bersama dengan satu tempat } & $\mathrm{Ya}$ & 36 & 90,0 & 15 & 18,8 & 51 & 42,5 & 0,00 & 39 & $12,04-126,4$ \\
\hline & Tidak & 4 & 10,0 & 65 & 81,2 & 69 & 57,5 & & & \\
\hline \multirow[t]{2}{*}{ Kebiasaan jajan } & $\mathrm{Ya}$ & 37 & 92,5 & 47 & 58,8 & 84 & 70,0 & 0,00 & 8,66 & $2,46-30,47$ \\
\hline & Tidak & 3 & 7,5 & 33 & 41,3 & 36 & 30,0 & & & \\
\hline
\end{tabular}

Tabel 4. Hasil Analisis Multivariat Regresi Binari Logistik antara Variabel Kandidat Kejadian Hepatitis A

\begin{tabular}{lllll}
\hline Variabel & b & Nilai p & OR & CI 95\% \\
\hline Umur & 0,89 & 0,25 & 2,45 & $0,54-11,16$ \\
Cuci alat makan pakai sabun & 0,01 & 0,99 & 1,01 & $0,09-10,91$ \\
Konsumsi air masak & 0,18 & 0,84 & 1,19 & $0,22-6,39$ \\
Tukat menukar alat makan & 1,73 & 0,02 & 5,65 & $1,35-23,69$ \\
Makan bersama dalam satu tempat & 3,03 & 0,00 & 20,62 & $3,85-110,49$ \\
Status imunisasi & $-3,60$ & 0,02 & 0,03 & $0,00-0,54$ \\
Kualitas tempat cuci tangan & 23,38 & 1,00 & 1,43 & 0,00 \\
Kebioasaan jajan & 1,08 & 0,21 & 2,93 & $0,54-15,80$ \\
Konsumsi makanan masak & 20,71 & 0,99 & 9,87 & 0,00 \\
\hline Constant & $-45,85$ & 0,99 & 0,000 & \\
\end{tabular}

memiliki nilai $\mathrm{p}<0,25$. Hasil analisis didapatkan bahwa kandidat yang masuk ke multivariat adalah variabel usia, cuci alat makan pakai sabun, konsumsi makanan masak, konsumsi air masak, tukar menukar alat makan, makan bersama dalam satu tempat, status imunisasi, kualitas tempat cuci tangan, dan kebiasaan jajan. Pembuatan model faktor penentu kejadian hepatitis A pada siswa/siswi di pondok pesantren X. Dalam pemodelan ini semua variabel dianalisis secara bersamaan. Pembuatan model dilakukan dengan memasukan semua variabel independen yang memenuhi syarat (Tabel 4).

Dari hasil analisis terlihat ada 6 variabel dengan nilai ( $p>0,05)$ yaitu umur, cuci alat makan, konsumsi air masak, konsumsi makanan masak, kualitas tempat cuci alat yang terbesar kualitas tempat cuci tangan sehingga pemodelan selanjutnya mengeluarkan variabel dengan nilai $p>0,05$. Pengeluaran variabel tidak dilakukan secara serentak, namun secara berurutan dikeluarkan variabel kualitas tempat cuci tangan, konsumsi masakan masak, cuci alat makan pakai sabun, konsumsi air masak, umur, dan kebiasaan jajan. Setelah semua variabel kandidat dengan nilai $p>0,05$ dikeluarkan, maka model akhir analisis multivariat dapat dilihat pada Tabel 5 .

Dari Tabel 5 dapat disimpulkan variabel yang paling dominan untuk terjadinya hepatitis A di Pondok Pesantren, yaitu kebiasaan makan bersama dalam satu tempat, tukar menukar alat makan dengan teman dan status imunisasi.

Model persamaan regresi logistik yang diperoleh dari hasil akhir analisis multivariat adalah sebagai berikut :

Logit $\mathrm{P}(\mathrm{Y})=-1,460+3,067$ (makan bersama dalam satu tempat) $+1,816$ (tukar menukar alat makan) + 2,881 (status imunisasi).

Sehingga risiko kejadian hepatitis A pada responden 
Tabel 5. Model Akhir Analisis Multivariat Regresi Logistik antara Variabel Kandidat Kejadian Hepatitis A Siswa/Siswi Pondok Pesantren X Kabupaten Ciamis

\begin{tabular}{lllll}
\hline Variabel & b & Nilai p & OR & CI 95\% \\
\hline Tukat menukar alat makan & 1,816 & 0,003 & 6,149 & $1,85-20,48$ \\
Makan bersama dalam satu tempat & 3,067 & 0,000 & 21,476 & $5,42-85,18$ \\
Status imunisasi & $-2,881$ & 0,020 & 0,056 & $0,01-0,64$ \\
\hline Constant & $-1,460$ & 0,002 & 0,232 & \\
\hline
\end{tabular}

apabila terbiasa makan bersama dalam satu tempat, terbiasa tukar menukar alat makan, dan tidak pernah diimunisasi hepatitis A adalah 3,36.

\section{Pembahasan}

Hasil analisis menunjukan umur tidak berhubungan dengan kejadian hepatitis A. Hasil penelitian ini bertentangan dengan hasil penelitian Rachim, ${ }^{10}$ yang menyatakan umur berhubungan dengan kejadian hepatitis A dengan nilai $p=0,004$. Hasil lain yang sejalan adalah penelitian Afudin, ${ }^{11}$ menyatakan ada hubungan yang signifikan antara umur dan kejadian Hepatitis A dengan OR $=3,496$. Kasus hepatitis A yang terjadi di pondok pesantren ini, bila dilihat secara univariat sesuai dengan hasil penelitian dan teori di atas, namun setelah dianalisis dengan bivariat dan multivariat ternyata umur tidak berpengaruh terhadap kejadian hepatitis A. Keadaan ini mungkin disebabkan sebaran umur pada kasus dan kontrol hampir sama. Sedangkan pada penelitian Rachim dan Afudin, umur respondennya bervariasi. ${ }^{10,11}$

Hasil analisis univariat diperoleh bahwa kasus banyak terjadi pada siswa/siswi MAN yaitu 52,5\%. Hasil analisis bivariat menunjukan tidak ada hubungan antara sekolah dengan kejadian hepatitis A dengan nilai $\mathrm{p}=0,648$. Keadaan ini tidak sesuai dengan beberapa hasil penelitian sebelumnya yang menyatakan tingkat pendidikan mempunyai hubungan yang bermakna dengan kejadian hepatitis A yaitu Rachim, ${ }^{10}$ dengan nilai $p=0,000$, Firdaus, ${ }^{12}$ dengan nilai $\mathrm{OR}=2,307$. Tidak adanya hubungan antara sekolah dengan kejadian hepatitis A di pondok pesantren ini mungkin terjadi karena tingkatan pendidikan antara MTs dan MAN tidak terlalu jauh sehingga ilmu yang didapat juga tidak terlalu banyak perbedaan, dan keadaanya berbeda dengan sekolah umum, karena mereka tinggal di asrama, banyak kegiatan yang dilakukan secara bersama-sama antara murid MTs dan MAN.

Hasil analisis bivariat menunjukan tidak ada hubungan antara jenis kelamin dengan kejadian hepatitis A dengan nilai $p=1,00$. Hasil penelitian ini sejalan dengan hasil penelitian Sumarsinah, ${ }^{13}$ menyatakan tidak ada hubungan antara jenis kelamin dengan kejadian Hepatitis dengan nilai $\mathrm{p}=0,377$. Namun, hasil ini bertentangan dengan hasil penelitian Rachim, ${ }^{10}$ yang menyatakan ada hubungan bermakna antara pendidikan dengan terdapatnya antibodi hepatitis A dengan $O R$ 1,81. Kejadian hepatitis A di pondok pesantren ini tidak dipengaruhi jenis kelamin, hal ini disebabkan karena kegiatan antara laki-laki dan perempuan sama, baik kegiatan yang berhubungan dengan sarana sanitasi dasar atau kegiatan sehari-hari diantara keduanya tidak berbeda. Sedangkan pada penelitian Rachim, ${ }^{10}$ respondennya masyarakat umum dengan kegiatan yang bervariasi antara laki-laki dan perempuan.

Hasil perhitungan statistik melalui analisis bivariat diperoleh status imunisasi memengaruhi kejadian hepatitis A dengan nilai $p=0,001$. Hasil penelitian ini sejalan dengan penelitian lainnya yang menyatakkan bahwa secar khus pencegahan penyakit hepatitis A dapat dilakukan dengan imunisasi, baik imunisasi pasif. ${ }^{14,15} \mathrm{Di}$ Amerika serikat, pemberian imunisasi terbukti menurunkan kematian selama 1 dekade. ${ }^{16}$ secara khusus pencegahan penyakit hepatitis A dapat dilakukan dengan imunisasi, baik imunisasi pasif. Data status imunisasi yang diperoleh hanya melalui kuesioner tanpa melihat bukti fisik, begitu juga dengan tanggal pelaksanaan imunisasi hepatitis A tidak ditanyakan sehingga untuk lebih memperkuat hasil penelitian ini perlu dilakukan penelitian lebih lanjut dengan memperhatikan efektivitas vaksin, waktu pelaksanaan imunisasi dan bukti fisik pelaksanaan imunisasi hepatitis A.

Pendekatan klasik untuk menemukan virus hepatitis A adalah melalui air. ${ }^{17}$ Dalam penelitian ini hubungan kualitas air bersih dan kejadian hepatitis A tidak bisa dianalisis, karena untuk keperluan minum antara kasus dan kontrol menggunakan air dari sumber yang sama. Hasil observasi terhadap kualitas fisik air bersih dilakukan dengan pancaindera dan hasilnya untuk semua sumur memenuhi syarat, yaitu tidak berasa, tidak berbau, tidak berwarna dan tidak keruh. Parameter bakteriologi yang diperiksa adalah Escherecia coli (E. coli), hal ini dilakukan menurut konsep fail safe yang maksudnya bila air positif tercemar tinja, maka diasumsikan bahwa dalam air tersebut juga mengandung kuman patogen, demikian juga sebaliknya. Parameter bakteriologi yang dapat digunakan adalah E. coli dan total coliform. ${ }^{18}$ Hasil penelitian yang menyatakan ada hubungan yang bermakna antara kualitas air bersih dengan kejadian hep- 
atitis A, Afudin, ${ }^{11}$ menyatakan orang yang menggunakan air yang tidak memenuhi syarat bakteriologis berisiko 3,8 kali dibandingkan responden yang menggunakan air memenuhi syarat bakteriologis. Meskipun hasil penelitian ini tidak dapat dianalisis secara statistik, namun berdasarkan teori-teori dan hasil penelitian ada baiknya kita harus selalu memperhatikan dan menjaga kualitas bakteriologis air yang kita gunakan dengan selalu menjaga kebersihan dan merawat sarana air bersih serta melakukan desinfeksi terhadap air.

Dalam penelitian ini, hubungan kualitas sarana air bersih dan kejadian hepatitis A tidak bisa dianalisis, karena untuk keperluan minum kasus dan kontrol menggunakan sumber air yang sama, yaitu sumur 1 dengan kualitas sarana tidak memenuhi syarat. Menurut Sarudji, ${ }^{19}$ untuk mendapatkan air yang bersih dan berkualitas dibutuhkan sarana air bersih yang memenuhi syarat. Persyaratan sarana tersebut meliputi lokasi dan kontruksinya. Hasil penelitian Rachim, ${ }^{10}$ menyatakan ada hubungan yang bermakna antara sumber air sarana tidak terlindung dengan kejadian hepatitis A dengan nilai $\mathrm{p}=$ 0,000 . Sedangkan hasil penelitian Afudin, ${ }^{11}$ menyatakan tidak ada hubungan yang bermakna antara sumber air dengan infeksi hepatitis A.

Hasil observasi terhadap kualitas jamban, diperoleh hasil hanya $36,4 \%$ yang memenuhi syarat. Sedangkan hasil analisis bivariat diperoleh nilai $\mathrm{p}=0,549$ yang berarti tidak ada hubungan antara kualitas jamban keluarga dengan kejadian hepatitis A. Penyebaran penyakit hepatitis A melalui jalur fecal-oral dan sangat dipengaruhi oleh keadaan sanitasi termasuk keadaan jamban. ${ }^{14}$ Hal ini sesuai juga dengan hasil penelitian Firdaus, ${ }^{12}$ yang menyatakan ada hubungan yang bermakna antara variabel kualitas jamban dengan kejadian hepatitis A dengan nilai $\mathrm{OR}=10,060$. Dalam penelitian ini tidak ada hubungan antara kualitas jamban keluarga dengan kejadian hepatitis A, disebabkan pemakaian jamban yang tidak tetap antara kasus dan kontrol. Kadangkadang memakai jamban yang memenuhi syarat atau sebaliknya. Untuk mencegah penularan penyakit lewat jamban maka seluruh siswa/siswi harus menjaga kebersihan jambannya masing-masing.

Hasil analisis bivariat hubungan kualitas tempat cuci tangan dengan kejadian hepatitis $\mathrm{A}$ diperoleh nilai $\mathrm{p}=$ 0,333 , yang berarti tidak ada hubungan antara kualitas tempat cuci tangan dengan kejadian hepatitis A. Tempat cuci tangan yang ada di pondok pesantren secara kualitas memenuhi syarat, namun secara kuantitas tidak mencukupi karena jumlahnya yang kurang. Hanya ada dua tempat cuci tangan, yaitu di tempat penyajian makan asrama putri dan asrama putra. Apabila mengikuti Peraturan menteri Kesehatan no. 1096 tahun 2011, bila jumlah santri di asrama perempuan ada 260 orang seharusnya ada tempat cuci tangan sebanyak 26 buah. ${ }^{20}$
Dalam penelitian ini, keadaan higiene sanitasi tempat makan tidak dapat dianalisis secara statistik, karena paparan tempat makan yang tidak memenuhi syarat terjadi pada kasus dan kontrol secara keseluruhan. Menurut Sulaiman dan Julitasari, ${ }^{14}$ salah satu pencegahan hepatitis A adalah dengan mencegah kontaminasi makanan dan minuman, dan yang bisa dilakukan di asrama ini adalah dengan memindahkan tempat makan ke ruangan yang tertutup dan proses pengangkutan makanan jadi dari dapur ke tempat makan harus tertutup.

Dalam penelitian ini, hasil analisis menyatakan tidak ada hubungan antara kebiasaan cuci tangan sebelum makan maupun alat makan/minum dengan kejadian hepatitis A dengan nilai $\mathrm{p}=0,598$. Hasil penelitian ini bertentangan dengan hasil penelitian Firdaus, ${ }^{12}$ yang menyatakan praktik mencuci tangan merupakan faktor risiko terjadinya hepatitis A dengan $\mathrm{OR}=3,442$. Hal ini sejalan dengan hasil penelitian Rachim (2004) yang menyatakan ada hubungan yang bermakna antara mencuci tangan sebelum makan dengan kejadian hepatitis A dengan nilai $\mathrm{p}=0,001$ dan $\mathrm{OR}=2,669$, namun tidak ada hubungan antara mencuci alat makan/minum dengan sabun. Kebiasaan cuci tangan di pondok pesantren ini tidak berhubungan dengan kejadian hepatitis A karena air yang biasa responden gunakan untuk mencuci tangan tidak memenuhi syarat secara bakteriologis sehingga mengontaminasi tangan dan dapat mencemari makanan.

Dalam penelitian ini, hasil analisis menyatakan tidak ada hubungan antara kebiasaan cuci tangan setelah $\mathrm{BAB}$ dengan kejadian hepatitis A dengan nilai $p=0,298$. Hasil penelitian ini tidak sejalan dengan hasil penelitian Afudin, ${ }^{11}$ yang menyatakan kebiasaan mencuci tangan setelah $\mathrm{BAB}$ berhubungan sangat bermakna dengan kejadian hepatitis $\mathrm{A}$ dengan nilai $\mathrm{p}=0,000$ dan $\mathrm{OR}=$ 4,688. Tidak adanya hubungan antara cuci tangan setelah $\mathrm{BAB}$ dengan kejadian hepatitis A di pondok pesantren bukan berarti personal hygiene tidak penting dalam pencegahan penyakit hepatitis A. Akan tetapi, dalam penelitian ini ada variabel lain yang lebih dominan. Untuk memutus mata rantai penularan hepatitis A, salah satunya adalah dengan memperbaiki kebersihan pribadi (personal hygiene) dan diantaranya adalah cuci tangan dengan benar.

Hasil analisis menyatakan ada hubungan antara kebiasaan minum air yang dimasak dengan kejadian hepatitis A dengan nilai $\mathrm{p}=0,017$ dan odd ratio 3,769. Hasil penelitian lain yang menyatakan ada hubungan yang bermakna antara kebiasaan minum air mentah dengan kejadian hepatitis E adalah Sumarsinah, ${ }^{13}$ dimana hasilnya $O R=5,46(95 \% C I: 3,17-9,41)$. Sejalan pula dengan hasil penelitiannya Corwin, ${ }^{21}$ yang menyatakan ada hubungan yang bermakna antara kebiasaan minum air mentah dengan kejadian hepatitis. Hasil penelitian yang bertentangan dengan hasil penelitian ini adalah 
Rachim, ${ }^{10}$ yang menyatakan tidak ada hubungan yang bermakna antara kebiasaan minum air yang tidak dimasak dengan kejadian hepatitis A dengan nilai $\mathrm{p}=$ 0,133 .

Hasil analisis menyatakan tidak ada hubungan antara kebiasaan $\mathrm{BAB}$ di jamban dengan kejadian hepatitis A dengan nilai $p=0,716$. Hasil penelitian yang sama dengan hasil penelitian ini adalah Rachim, ${ }^{10}$ yang menyatakan tidak ada hubungan yang bermakna antara kebiasaan $\mathrm{BAB}$ di jamban dengan kejadian hepatitis A dengan nilai $p=0,093$. Tidak adanya hubungan antara kebiasaan BAB di jamban dengan kejadian hepatitis A karena kualitas jamban masih $63,6 \%$ belum memenuhi syarat, yang disebabkan keadaan jamban yang kotor, tidak ada sabun, lantai retak-retak dan pintu yang tidak menutup sempurna.

Dalam penelitian ini hasil analisis menyatakan ada hubungan antara kebiasaan tukar menukar alat makan dengan kejadian hepatitis A dengan nilai $\mathrm{p}=0,000$ dan odd ratio. ${ }^{21}$ Kebiasaan tukar menukar alat makan sesama teman sudah terbiasa dilakukan responden, baik siswa maupun siswi. Alat makan atau minum yang mereka pakai kadang saling bergantian. Padahal dari alat makan ini kemungkinan penularan penyakit terjadi, apalagi hepatitis A ini sebelum gejala kelihatan sudah bisa menularkan virusnya pada orang lain. Untuk merubah perilaku siswa/siswi ini harus melalui sosialisasi mengenai Perilaku Hidup Bersih Dan Sehat serta pengetahuan mengenai peranan makanan dan minuman dalam penularan penyakit. Sosialisasi yang dilakukan harus semenarik mungkin, melalui media film atau pamflet dengan gambar yang menarik.

Dalam penelitian ini hasil analisis menyatakan ada hubungan antara kebiasaan makan bersama dalam satu tempat dengan kejadian hepatitis $\mathrm{A}$ dengan nilai $\mathrm{p}=$ 0,000 . Hasil penelitian yang sesuai dengan penelitian lain yang menyatakan, kebiasaan makan bersama dalam satu tempat merupakan faktor yang berkontribusi dalam kejadian hepatitis A dengan $\mathrm{OR}=5,76 .{ }^{22}$ Kebiasaan makan bersama antar responden merupakan hal biasa. mereka menganggap kebiasaan ini sebagai bentuk kebersamaan, apalagi dikalangan siswi satu piring untuk makan bertiga atau berempat sambil ngobrol, begitu juga dengan tempat minum.

Dalam penelitian ini hasil analisis bivariat menyatakan ada hubungan antara kebiasaan jajan dengan kejadian hepatitis A dengan nilai $\mathrm{p}=0,00$ dan odd ratio 8,67 . Menurut Sumarsinah, ${ }^{13}$ kebiasaan jajan diperkirakan merupakan faktor risiko terjadinya infeksi $H A V$, karena peralatan makan/minum yang digunakan dicuci dengan air yang kualitas bakterilogisnya tidak memenuhi syarat.

Penentuan variabel yang paling dominan dilakukan dengan menggunakan uji regresi logistik, mulai dari taha- pan pemilihan variabel kandidat multivariat, pembuatan model faktor penentu, dan penentuan model akhir.

Model persamaan regresi logistik kejadian hepatitis A di pontren $\mathrm{X}$ adalah :

Logit $\mathrm{P}(\mathrm{Y})=-1,460+3,067$ (makan bersama dalam satu tempat) $+1,816$ (tukar menukar alat makan) + 2,881 (status imunisasi).

Sehingga risiko kejadian hepatitis A pada responden apabila terbiasa makan bersama dalam satu tempat, terbiasa tukar menukar alat makan, dan tidak pernah diimunisasi hepatitis A adalah 3,36.

\section{Kesimpulan}

Kondisi kesehatan lingkungan di Pondok Pesantren X yang meliputi kualitas fisik air bersih dan kualitas tempat cuci tangan seluruhnya memenuhi syarat, sedangkan kualitas bakteriologi air, sarana air bersih, jamban, tempat pengelolaan makanan dan tempat makan sebagian besar $(>50 \%$ ) belum memenuhi syarat. Sebagian besar $(>50 \%)$ responden sudah melakukan perilaku hidup bersih dan sehat. Variabel yang memiliki hubungan bermakna dengan kejadian hepatitis A yaitu makan bersama dalam satu tempat, tukar menukar alat makan, dan status imunisasi.

\section{Daftar Pustaka}

1. Departemen Kesehatan Republik Indonesia. Undang-Undang Republik Indonesia, nomor 36 Tahun 2009 tentang Kesehatan. Jakarta: Departemen Kesehatan Republik Indonesia; 2009.

2. Kemmer NM, Miskovsky EP. Hepatitis A. Infectious Disease Clinics of North America. 2000: 14; 605-15.

3. WHO. Hepatitis A [fact sheet online]. 2008 [ cited Jul 26 2012]. Available from: http://www.who.int/entity/mediacentre/factsheets/ fs204/en/.

4. Yong HT, Son R. Hepatitis A virus: a general overview. International Food Research Journal. 2009; 16: 455-67.

5. Departemen Kesehatan Republik Indonesia. Buku pedoman PHBS. Jakarta: Departemen Kesehatan Republik Indonesia; 2011.

6. Dinas Kesehatan Kabupaten Ciamis. Laporan surveillans KLB hepatitis A tahun 2012. Ciamis: Dinas Kesehatan Kabupaten Ciamis; 2012.

7. Lemeshow S. Besar sampel dalam penelitian kesehatan. Yogyakarta: Gajah Mada University Press; 1997.

8. Murti B. Prinsip dan metode riset epidemiologi. Yogyakarta: Gajah Mada University Press; 2003.

9. Hastono SP. Analisis data kesehatan. Depok: Fakultas Kesehatan Masyarakat Universitas Indonesia; 2007.

10. Rachim A. Hubungan penggunaan sumber air sarana tidak terlindung dengan kejadian Hepatitis A di Kecamatan Seputih Raman Kabupaten Metro Lampung tahun 2000 [tesis]. Jakarta: Fakultas Kesehatan Masyarakat Univeristas Indonesia; 2004.

11. Afudin. Faktor-faktor yang berhubungan dengan kejadian infeksi hepatitis A virus (HAV) di Kabupaten Kebumen tahun 2001 [tesis]. Jakarta: Fakultas Kesehatan Masyarakat Univeristas Indonesia; 2003.

12. Firdaus U. Hubungan praktek cuci tangan sebelum makan dengan keja- 
dian hepatitis A Desa Cogreg Kecamatan Parung Kabupaten Bogor tahun 2001 - 2002 [tesis]. Jakarta: Fakultas Kesehatan Masyarakat Univeristas Indonesia; 2002.

13. Sumarsinah. Beberapa faktor risiko yang berhubungan dengan penyakit hepatitis E pada kejadian luar biasa hepatitis di Kabupaten Bondowoso Jawa timur tahun 1998 [tesis]. Jakarta: Fakultas Kesehatan Masyarakat Univeristas Indonesia; 2000.

14. Sulaiman A, Julitasari. Virus hepatitis A sampai E di Indonesia,. Jakarta: Yayasan Penerbit Ikatan Dokter Indonesia; 1995.

15. Dienstag Jl. Hepatitis A: the vaccine dividend. The Journal of Infectious Desease. 2008; 197 (2): 1220-2.

16. Vogt Tm, Wise ME, Bell BP, Finneli L. Declining hepatitis A mortality in the United States during era hepatitis A vaccination. The Journal of Infectious Disease. 2008; 197: 1282-8.

17. Nainan OV, Xia G, Vaughan G, Margous HS. Diagnosis of hepatitis A infection: a molecular approach. Clinical Microbiology Review. 2006: 63-79.
18. World Health Organization. Guidelines for drinking-water quality. 2nd ed. Geneva: World Health Organization; 1996.

19. Sarudji D. Kesehatan lingkungan. Jakarta: CV Karya Putra Darwati; 2010.

20. Kementrian Kesehatan Republik Indonesia. Peraturan Menteri Kesehatan RI Nomor 2269/Menkes/Per/XI/2011 tentang pedoman perilaku hidup bersih dan sehat (PHBS). Jakarta: Kementerian Kesehatan Republik Indonesia; 2011.

21. Corwin A, Putri MP, Winarno J, Lubis I, Suparmanto S, Sumardiati A, et al. Epidemic and sporadis hepatitis A virus transmission in West Kalimantan (Borneo), Indonesia. American Journal of Tropical Medicine and Hygiene. 1997; 57 (1): 62-5.

22. Dwiastuti S. Hubungan antara faktor lingkungan dan perilaku dengan kejadian hepatitis A pada Taruna Akademi Kepolisian tahun 2008 [tesis]. Semarang: Fakultas Kesehatan Masyarakat Universitas Diponegoro; 2008. 